\title{
Health and well-being: art therapy for health professionals working in outpatient care settings
}

Saúde e bem-estar: a arteterapia para profissionais de saúde atuantes em cenários de cuidado ambulatorial

\section{Salud y bienestar: el arteterapia para profesionales de salud actuantes en escenarios de atención} ambulatoria

\author{
Oneide Regina Depret $^{1}($ ) \\ Edmara Bazoni Soares Maia ${ }^{1}$ (1) \\ Regina Issuzu Hirooka de Borba ${ }^{1}$ (1) \\ Circéa Amália Ribeiro ${ }^{1}$ (iD)
}

1. Universidade Federal de São Paulo, Escola Paulista de Enfermagem. São Paulo, SP, Brasil.
Corresponding author:

Oneide Regina Depret.

E-mail: oneidepret@gmail.com

Submitted on 06/29/2019.

Accepted on 08/12/2019.

DOI: 10.1590/2177-9465-EAN-2019-0177

\begin{abstract}
Objectives: To enable health professionals, in an outpatient care setting, to experience the group process of art therapy and to understand the meaning given by him/her to this experience. Method: A qualitative study, using Symbolic Interactionism and Qualitative Conventional Content Analysis as theoretical and methodological frameworks, respectively. Eight health professionals working in the outpatient clinic of a philanthropic institution participated in the art therapy process and later in semi-structured interviews. Results: For the professionals, art therapeutic workshop was an amazing and rewarding experience, a space of interaction that allowed them to know each other better, to respect and learn from their colleagues, to relax, relieve stress and express their emotions. It was defined as a therapeutic experience, promoter of health and well-being, prompting professionals to want the workshops to continue. Conclusions and implications for practice: The study contributes to the reflection and discussion about workers' health and to the need to create therapeutic resources, such as art therapy, as a support tool for their mental health and well-being. Innovative and creative interventions must be incorporated into health services to address the global clamor, emphasizing the need to promote mental health, especially for health professionals, which calls for urgent measures.
\end{abstract}

Keywords: Art Therapy; Occupational Health; Mental Health; Humanization of assistance.

\section{Resumo}

Objetivos: Possibilitar ao profissional de saúde, em cenário de cuidado ambulatorial, a experiência de processo grupal de arteterapia e compreender o significado atribuído por ele a esta vivência. Método: Estudo qualitativo, tendo o Interacionismo Simbólico como referencial teórico e a Análise Qualitativa de Conteúdo Convencional, como metodológico. Oito profissionais de saúde atuantes no ambulatório de uma instituição filantrópica participaram do processo arteterapêutico e posterior entrevista semiestruturada. Resultados: Para os profissionais, a oficina arteterapêutica constituiu-se em vivência surpreendente $e$ gratificante, espaço de interação que lhes possibilitou conhecer-se melhor, respeitar e aprender com os colegas, relaxar, aliviar o estresse e expressar suas emoções. Foi definida como uma experiência terapêutica, promotora de saúde e bem estar, o que fez emergir o desejo de sua continuação. Conclusões e implicações para a prática: $O$ estudo contribui para a reflexão e discussão sobre a saúde do trabalhador e a necessidade de criação de recursos terapêuticos, como a arteterapia, como suporte à sua saúde mental e bem estar. Intervenções inovadoras e criativas devem ser incorporadas nos serviços de saúde para atender ao clamor mundial, que enfatiza a necessidade de promover a saúde mental, em especial, dos profissionais de saúde, o que demanda medidas urgentes.

Palavras-chave: Terapia pela arte; Saúde do trabalhador; Saúde Mental; Humanização da assistência.

\section{RESUMEN}

Objetivos: Posibilitar al profesional de salud, en escenario de atención ambulatoria, la experiencia de proceso grupal de arteterapia y comprender el significado atribuido por él/ella a esta vivencia. Método: Estudio cualitativo, teniendo el Interacionismo Simbólico como referencial teórico y el Análisis Cualitativo de Contenido Convencional, como metodológico. Ocho profesionales de salud actuantes en el ambulatorio de una institución filantrópica participaron del proceso arteterapéutico y posterior entrevista semiestructurada. Resultados: Para los profesionales, el taller arteterapéutico constituyó una vivencia sorprendente y gratificante, espacio de interacción que les permitió conocerse mejor, respetar y aprender con los colegas, relajar, aliviar el estrés y expresar sus emociones. Se definió como una experiencia terapéutica, promotora de salud y bienestar, lo que hizo emerger el deseo de su continuación. Conclusiones e implicaciones para la práctica: El estudio contribuye a la reflexión y discusión sobre la salud del trabajador y la necesidad de crear recursos terapéuticos, como la arteterapia, como soporte a su salud mental y bienestar. Intervenciones innovadoras y creativas deben ser incorporadas en los servicios de salud para atender al clamor mundial, que enfatiza la necesidad de promover la salud mental, en especial, de los profesionales de salud, lo que demanda medidas urgentes.

Palabras clave: Terapia con arte; Salud Laboral; Salud Mental; Humanización de la atención. 


\section{INTRODUCTION}

Alarming data projected by the World Health Organization (WHO) predict an upward curve for illness related to mental health, and it is estimated that depression in 2020 will be the second leading cause of mental and disabling illness in the world population, rising to first cause in the world in 2030. This estimate triggered, by $\mathrm{WHO}$, in 2017 , the worldwide campaign "Depression: Let's Talk", with the overall goal that more people around the world seek help and talk about it. ${ }^{1}$

In Brazil, the prevalence of depressive symptoms and suicide is also high among health professionals. ${ }^{2}$ Research in this area has been carried out in different care contexts in order to detect and understand the psychological distress to which the worker in the area is exposed to, ${ }^{3-5}$ including anxiety, occupational stress, depression and Burnout Syndrome, which is characterized by symptoms of emotional exhaustion, job dissatisfaction and depersonalization or insensitivity to others. ${ }^{6}$

Integrative review points out that, among nursing professionals, there are numerous risk factors for depression and these are related to their own work environment, to human relationships and personal characteristics, in addition to the risk of suicide related to the presence of mental disorder. ${ }^{2}$ Studies are congruent to emphasize the need for interventions in this area, both to ensure the quality of customer service as well as their own health and well-being, adherence to the work environment and quality of life of the professional. ${ }^{2-7}$

Around the world, there is a growing interest in the use of the arts to serve clients and professionals working in health care settings, due to its physical and mental health promoting effect. ${ }^{8}$ The engagement of health professionals in artistic activities, such as art therapy programs, emerges as a possibility to meet the global health challenge proposed by WHO: the population's mental health care. ${ }^{1,9}$

Art therapy can be applied to individuals or groups in various places and contexts, and uses artistic expression as a therapeutic process, being able to promote the improvement of quality of life, personal development and contribute to mental health, ${ }^{10}$ which is defined as a state of well-being in which each individual realizes his or her own potential and can cope with normal life tensions, work productively, and contribute to the community. ${ }^{11}$

Recognized as a professional occupation, the art therapy approach was recently included in the National Policy for Integrative and Complementary Practices (NPICP), Ordinance No. 849/2017, becoming a practice provided by the Unified Health System (UHS $)^{12}$ as a possibility of attention and assistance both to the population and to the health professional, which is consistent with the assumptions of the National Humanization Policy (NHP). ${ }^{13}$
In this sense, we believe that programs that include art therapy for healthcare professionals can contribute positively to the current panorama of illnesses related to mental health and have a positive impact on the health and well-being of these workers. Thus, this study was proposed to answer the question: "How do health professionals working in primary health care settings interact with the opportunity to experience an art therapy process?" And it aimed to enable the health professional, in an outpatient care setting, to experience a group process of art therapy and to understand the meaning attributed by him/her to this experience.

\section{METHOD}

A qualitative approach study, whose theoretical framework was the Symbolic Interactionism, a perspective that focuses on the nature of human interaction, the social dynamics and the meanings that human beings attribute to objects and thus carry out their plans. ${ }^{14}$ The methodological framework was the Qualitative Analysis of Conventional Content, whose purpose is to describe a phenomenon through inductive analysis performed directly from the data obtained from the participants. ${ }^{15}$

The research was conducted in an outpatient philanthropic institution located in the southern region of the city of São Paulo, which is affiliated to the Unified Health System, which primarily serves the maternal and child population from socioeconomically underprivileged families with high social vulnerability. It is noteworthy that before the study was conducted, there was no close relationship between the researcher and the institution or the participants.

The recruitment of the professionals occurred by convenience, after the presentation of the research project and its approval by the institution's board, being then presented to a group of employees who were willing to know it, clarifying the objectives of the study and talking about the voluntary participation in an art therapy process to be held fortnightly during working hours. In the following days, the interested parties enrolled themselves directly with the head of the outpatient clinic, being organized in two groups, in order to ensure that the workers in the same sector could take turns and not affect the routine of the service, as well as promote the tranquility of the participants.

Twelve professionals participated in the two art therapy groups, eight of whom were interviewed for meeting the following inclusion criteria: being a professional working at the outpatient clinic, being available to participate in at least four of the six workshops held and individual interviews after the completion of the same study. Participants were between 23 and 63 years old: a social worker, two nurses, a nursing technician, two receptionists, an executive secretary and an accounting assistant. 
The research development took place in two stages. The first involved the art therapy process and the second, the qualitative interviews with the participants, which were conducted about six months after the art therapy process. Both occurred from July 2013 to June 2014.

The art therapy process had as theoretical and methodological support the one advocated by Bernardo, whose researches are reference in the field of Art Therapy. ${ }^{10,16,17}$ Thus, each workshop consisted of four moments: 1. Warm-up, group integration and presentation of the theme to be focused;2. Awareness through a story selected in accordance with this theme and performing corresponding expressive activity; 3 . Presentation of the work produced and comments on the elaboration of the experiment. 4. Closing and evaluation of the meeting. ${ }^{10}$

In total, with each group were held six workshops, fortnightly, with a duration of 1 hour and 30 minutes, at the institution itself and during the workday. The workshops were conducted by one of the researchers, psychologist and specialist in Art Therapy. Next, we will briefly present the proposal of each art therapy workshop.

$1^{\text {st }}$ Meeting: Beginning of the group process. Objectives: Presentation of the members and the proposal, with the creation of preserved interactional space. The story narrated as sensitization, "The Tale of Two Dreamers", by Jorge Luís Borges, ${ }^{18}$ tells of a Cairo resident who once dreamed that he would find a treasure in a distant Persian city. He undertook the trip and upon his arrival he was taken to the local authority. The cadi (judge) laughed at the traveler when he learned the reason for his trip, telling him that he had dreamed three times that he found treasure in the garden of a house in Cairo near a fountain, but had never been foolish enough to make such a trip. The traveler happily returned to his hometown. Arriving there, he dug and found the treasure in his own garden: he had recognized his own home in the dream of the cadi (judge).

Expressive activity performed: Making a box decorated with magazine images. ${ }^{10}$ Each participant was guided, inspired by the story they heard, to cut out figures from magazines that represented "their treasure", something they liked and attributed value to, in order to decorate the cardboard box to pack the work produced during the process. This is one of the expressive resources appropriate to the beginning of the group process, because it facilitates the creation of a welcoming space and promotes contact with the participants' own subjectivity, allowing them to introduce themselves and start creating a relationship of trust. ${ }^{10}$

$2^{\text {nd }}$ Meeting: Theme: Creating Bonds. Objective: Experience and value teamwork. Story: "Seven Spools of Thread", by A. S. Medearis, ${ }^{19}$ is an African tale that tells of seven brothers who are constantly fighting for whatever reason. When their father dies, he leaves them seven spools of silk thread and the instructions that they could only receive their inheritance if they were able to turn it into gold in just one day. The brothers were able to accomplish the feat when they realized that if they worked together cooperatively, they could make a beautiful colored fabric and sell it at a gold price. In the end, the brothers teach their art to the villagers.

Expressive Activity: Collective confection of the "eye of God", an art therapeutic resource that, when made in groups, has the purpose of stimulating cooperation and highlighting the need to value differences, ${ }^{10}$ attributes necessary for the promotion of healthy coexistence and the quality of teamwork.

$3^{\text {rd }}$ Meeting: Theme: Overcoming obstacles. Objective: To stimulate the ability to cope with difficulties. D. McKee's story ${ }^{20}$ "The Hill and the Rock", tells of a couple who live high on a mountain and receive many visitors drawn by the beauty of the landscape. It turns out that there is a large stone that covers half of the kitchen window, which is why the wife complains so much to her husband, that he, with great effort, pushes the stone down the mountain. From there, unusual facts happen. The stone covered a hole in the mountain, without it the mountain began to deflate like a balloon, turning into a valley. Until the stone rolled again and positioned itself in front of the same window, closing the hole through which the air escaped. The mountain grew back, and soon the house was up again. Her husband then came up with the idea of painting a landscape on the stone that covered the window. From then, the woman would tell the visitors that the most beautiful view was from the kitchen window.

Expressive Activity: Painting on stones. It is an appropriate resource for dissolving rigidity and promoting change of viewpoints and behaviors that are no longer effective or correspond to the participant's current needs. ${ }^{10}$

$4^{\text {th }}$ Meeting: Theme: Illuminating potentialities. Objective: Perception of positive and potential characteristics. E. Kressler's story ${ }^{21}$ "The Lantern Girl", tells of a girl who, seeking to light the fire of her lantern, walks through a forest and finds animals and people unwilling to help her. Finally reaches the top of a mountain, but very tired fell asleep. The sun, which had long seen her, at nightfall, approached and lit up the lantern. When she woke up, seeing her lantern lit, started her way back, and with the acquired fire she helped all the people she had encountered who were in the dark. The animals woke up with the glow of her lantern and so the girl returned happily to her home.

Expressive Activity: Making mandalas from melted candles. ${ }^{10}$ The fire element can symbolically be associated with awareness, the ability to illuminate what is obscure, to bring light to what is in the unconscious, being related to creativity and knowledge. ${ }^{18}$ Expressive activities using this element, such as the candle mandala, are designed to work on fear, promote self-confidence and the recognition of talents and potentials, and help focus. The visible face of the mandala, where the candle is dripped, is dark and ugly, while the other, which appears when turned after it is ready, is colorful and bright. 
$5^{\text {th }}$ Meeting: Theme: Rescuing your own story. Objective: To identify the process of personal development. The story of "Fatima, the Spinster" is a Greek tale retold by Regina Machado. ${ }^{22}$ It tells of a girl who lived on an island with her spinster parents. She goes through a series of setbacks in life, several times lost what she had and had to start over in a different place, but in each of them learned a new craft. She was a spinster, then learned to weave and make masts. Finally, she came to a land where there was a prophecy that a foreigner would be able to make a beautiful tent for the emperor. Fatima decided to try and, as she could not find suitable materials, she produced ropes, fabrics and stakes. Finally, just by remembering all the kinds of tents she had seen in her wanderings, she was able to build a beautiful tent for the emperor, who very gratefully promised her whatever she wanted. Fatima just wanted to live there and start her life over. She married and had children to whom she always said that everything that had seemed disgrace to her when it happened contributed to her ultimate happiness.

Expressive Activity: Making a rag. ${ }^{10}$ Symbolically, stories are related to yarns and threads, so sewing, weaving, and yarn work, such as making the rag, can be especially suited to providing a broad view of themselves and their own experiences. ${ }^{10}$

$6^{\text {th }}$ Meeting: Closing the process. Objective: Evaluation of the art therapeutic process. At this meeting, participants receive back the work produced, which had been with the researcher and is the moment when they can have a new look and comment on the set of activities performed, reflecting on what they experienced and learned during the process. ${ }^{10}$

The second stage of the research took place after the completion of the art therapy process and consisted of a semistructured, qualitative individual interview, previously scheduled with the participants and held at the institution itself. It was mediated by the trigger question: How was your experience of participating in art therapy workshops? During its course, other questions were inserted in order to deepen the understanding of the concepts expressed by the interviewee. The interviews were audio recorded and fully transcribed.

Qualitative data analysis was performed concurrently with data collection following the steps recommended by the methodological framework: coding, categorization, integration and description of the unveiled categories. ${ }^{15}$ After analysis, it was understood that the revealed data were considered well developed, with repetition of information that led to the understanding that the objective of the study had been achieved and no further interviews were necessary due to data saturation. ${ }^{23}$

The research was approved by the Research Ethics Committee of the proposing institution (CAAE: 07857312.3.0000.5505) and authorized by the participating institution. As determined by Resolution 466/12 of the National Health Council, the study participants signed the Informed Consent Form. In order to guarantee the anonymity of the participants and identify them in the transcription of excerpts from their statements, they were identified by the researchers by names of medicinal herbs.

\section{RESULTS}

The data revealed that, for the health professional, participating in the art therapy process represents a surprising, rewarding and therapeutic experience, playful and pleasant with effect on health and well-being. It made possible to reframe their experiences by interacting with the narrated stories, recognizing the importance of performing manual activities such as breathing pauses, relaxing and relieving the burden and stress of the workday.

The art therapy workshop is also an important space for interaction, which enables one to get to know him/herself better, to respect and learn from his/her colleagues, while being able to speak and express his/her emotions. It is defined as a therapeutic experience that promotes health and well-being, thus the desire for its continuation emerges.

\section{Being a playful and pleasurable experience}

The professional defines the art therapy experience as positive, satisfactory and important, consisting of playful and very special moments.

I liked very much. It was very, very, very, very good! I think this moment of Art Therapy, this moment of our meetings, was really very special. It was wonderful! What I experienced was extremely positive. It is a playful moment, an important moment. (Fennel)

Light. [...] because during the activities we talked, we laughed. [...] a moment of relaxation. (Chamomile)

\section{Surprising yourself by being a different experience}

Having little prior information about art therapy, by accepting the invitation to participate in the workshops, the professional says being motivated by curiosity, to learn what was happening in the institution or even to "get away from service". However, after experiencing the process, they evaluate that the experience was fruitful, engaging and interesting, enabling them to redefine the sense of participating in group activities.

I need to participate in order for me to really be sure how it works. Until I went, out of curiosity. [...] I always thought that: Oh! Let's do a work, let's do an interview with a psychologist... I always thought it was foolish. But I went, I enjoyed the first class. I said: No, I will continue, I will participate until the end, because I found it interesting. It was a surprise to me! It's nothing like what I thought before. (Sage) 
I never imagined it would bring all the benefits it brought, both professionally and personally. I didn't realize that in such a short time, so short, how much, how many changes! And good changes. (Fennel)

\section{Reframing their experiences when interacting with the stories}

The professional defines the stories presented as sources of inspiration, example and encouragement because, by interacting with them, they can learn and bring important lessons to their lives. Comparing with the characters and observing the attitudes they had towards the situations portrayed, they recognize their own characteristics and proceed to modifying attitudes that they considered to be inappropriate.

In all the stories, I think each one was bringing it to their life. [...] I remembered my problem, and how I could handle it better. Not to be discouraged, to transform the day to day... So, we start think everything in our life and always reflecting, in a positive way, an incentive. (Chamomile)

From each story you could take a lesson. The issue of overcoming, the story of the girl who learned, relearned and in the end she used it all. These are things that you bring to life, right? (Rosemary)

\section{Recognizing the importance of performing manual activity}

Interacting with manual, expressive and creative production, the professional discovers a pleasant, relaxing activity, coming to remember past experiences in which they experienced this pleasure, as well as planning, in the future, some time to introduce it into their routine.

The "eye of God" was one of the works I liked the most. The others I already had a little notion, sewing, riding, always my mother taught me how to do these little things. [...] When I have more time available, I will do for sure. Occupy the mind a little, divert a little from the stress. (Macela)

I had never made the thing of, let's call it, crafts. [...] I did not know that I had this ability to do! Such a thing, very pleasant! Calms down, improves concentration. Very good! (Rosemary)

\section{Art therapy being a breathtaking break}

The art therapy workshops are defined by the professional as moments when they could "breathe", relax and disconnect from problems and routine, even during the workday. Accustomed to getting involved in various tasks and always thinking about what has to be done, they reflect that the time dedicated to the meetings is a pause in their busy routine, a time really theirs, to interact with themselves and recover their energies.

The matter of taking a break for yourself too! It's great that you stop that time there and do the activities. Get some rest, think about yourself, not just goals, objectives or other people. Moreover, this break in our meetings, activities, made us ... stop! Because it is a break (from work) where you can replenish your energies. (Rosemary)

I think all this time I had never had a time for myself! (Fennel)

\section{Relaxing and relieving the load and stress}

The professional reflects that stress relief occurs both due to the feeling of relaxation arising from the dynamics established in the meetings, as well as the opportunity to vent and unload the tensions arising from daily work, such as the overload of activities and excessive demands that they believe to suffer.

It makes me relax. I thought it was very important because when we came to attend the meetings, I think that in the end it gave that feeling of relief, as if it pleased! Felt in all (the colleagues), all. You realize it was general. This work gives more peace of mind. (Melissa)

\section{Respecting, getting to know each other better and learning from colleagues}

Having the opportunity to see and hear the colleague in a different situation from the routine allows the participant to get to know, understand and respect the co-worker better. He assesses that this contact favors the modification of any misconceptions and preconceived ideas that may have, providing better coexistence of the group in daily life.

Because we look like this and think: each one with their problems. But it's not like that! We have to see the others too. Because company is that thing: John Doe only gets paid and doesn't even appear here, John Doe doesn't come here and I don't know what John Doe just cries ... But nobody knows what the guy is going through. Then, after you are there, together, you see the situation. Gosh, I made a bad judgment of the person. Because you get to know. And then you change. (Mint)

The dialogue, it is very important. Because we learn a lot from people. Everyone has something good to offer. (Rosemary) 


\section{Being an important space for talking and expressing emotion}

The participant observes that during the process, a climate of trust and intimacy that favors the expression of personal issues is installed in the group. He/she evaluates that both he/ she gets to know his/her colleagues better and lets him/herself be known by them, naturally speaking about personal issues and expressing their emotions.

I found it very important. For example, now, just the fact that we are talking, you also pass this tranquility, pass this feeling, you are so, putting things in a way that we have confidence to pass. (Melissa)

Because sometimes you were stressed, and there (in the workshop) you could get out what you were feeling by doing the activities. You did it and then you had to comment on what you did. So that was already a way for you to vent what you were feeling. (Lavender)

\section{Being a therapeutic experience}

By participating in the workshops, the professional starts to see things differently, even changing postures and attitudes; they have the opportunity to discover and strengthen themselves, to develop potentials such as the ability to concentrate, selfconfidence and self-esteem, to give new value and meaning to the process of self-awareness and then to define the experience as a true therapy.

So that was good for me, it slightly improved my selfesteem. (Macela)

I saw more difference in me. Ah! You can see things more clearly. Seeing the other side of things was good. So sometimes you would think about what happened (in the workshop) and go home well. (Chamomile)

It was a good lesson I had. One for thinking it was silly to participate! It was like this until the end of the course: every time we met, I was learning more and more. It was a wonderful lesson for me, I learned a lot. I think I grew up! (Sage)

\section{Wishing the continuity of the art therapy process}

Considering the challenges of institutional work, the lack of effective support to help the professional to cope with the daily difficulties and recognizing the benefits provided by the art therapy process, such as relaxation and stress relief, the participant believes that it is interesting to continue the service provided and to be extended to all sectors of the institution.

I thought it was very important to participate in this process, both for me and for the team that was with me. (Melissa)
What you find the most here are stressed people. In general, everyone needs it. If everyone went to therapy, they would work harder, not discourage, not stress. (Lavender)

And for me it had a big comeback. Because it was a job that was well executed here at the institution and that had a certain return. A lot of it! So it helps, people have to embrace it because it's good. (Mint)

\section{DISCUSSION}

Accustomed to interacting with problems and suffering of various kinds, when having the opportunity to talk about his/her participation in the art therapy process, the health professional expresses how healthy and pleasant the experience was, permeated by moments of relaxation and lightness in the work environment. There is growing evidence of the effectiveness of art therapy in reducing stress, anxiety and mood improvement in different populations and contexts of applicability, from its different modalities such as dance, music and manual artistic interventions, ${ }^{9,24}$ the latter being used in this study.

The playfulness was present when, by interacting with the expressive resources available in the workshops, the professional comes to recognize the importance of performing manual activity. $\mathrm{He} / \mathrm{she}$ says he/she feels pleasure in the handling of the materials and in the novelty of the proposals, even relating it to pleasant situations experienced in childhood, perhaps because it is the phase in which it is usual to have freedom to create and experiment, to do something without definite purpose, just for the pleasure, attitude that the adult often leaves aside, with so many responsibilities and obligations. Highlighting and valuing the playful aspect of art therapy workshops, associating it with the pleasant memory of the past also occurred with athletes. ${ }^{25}$

By participating in the art therapy process, professionals realized the possibility of interacting with colleagues differently than usual, learning, easily exposing their emotions and feelings, obtaining personal and group benefits in a seemingly unpretentious and so unimportant but rich and engaging situation. This benefit is also reported in studies that indicate the improvement and strengthening of relationships in the workplace after the health team's engagement in artistic activities. ${ }^{8,9}$ Art therapy workshops can foster closer ties, creating greater trust and intimacy even among people who already had a friendly relationship, as researches conducted with athletes ${ }^{25}$ and also with health professionals show. ${ }^{8}$

It should be considered that interactions between team members do not always occur in a climate of tranquility and cooperation, ${ }^{26}$ and the conflicting relationship with the boss and colleagues is pointed as one of the major factors that generate psychological distress, anxiety and stress for the professional. ${ }^{4,27,28}$ 
It is noteworthy that in this study, job titles, education, and hierarchical position made no difference: relationships became humanized, participants began to see different aspects of each other, to review concepts and reassess opinions they had about each other, finding a space to talk and express emotion with confidence and tranquility, respecting and feeling respected.

Surprising was the involvement of the health professional with the stories told in the workshops: they "traveled" along with the characters, were thrilled and lived their dramas, learning from them new ways to deal with situations, thus reframing their experiences by interacting with the stories. Putting themselves in the place of the character, they identified similarities in attitudes which they deemed positive, then feeling strengthened and valued; they also recognized themselves in attitudes which they considered negative, coming to revise their views and attitudes in the face of some situations, seeking to modify their way of acting.

The literature argues that storytelling gives the listener a distance from their reality, allowing them to broaden their view of themselves and their current situation, giving new meanings to their history, giving new meaning to what has already been lived and seeing new ways out of the faced conflicts, because when they take the place of the characters, they see themselves "from the outside", as when climbing a mountain to have a broader view of the landscape, coming to the possibility of engaging in a dialogue with their own selves. ${ }^{10}$

It was evident that participating in art therapy meetings was a pause for breathing within the busy routine of the outpatient clinic. The practitioner recognizes that engaging in artistic activities has a positive impact on their health and well-being, as well as improving communication with clients, helping to build an empathic relationship. Studies have also found positive effects such as stress reduction, mood enhancement, increased work performance, burnout reduction and feeling of well-being. ${ }^{7,9}$

Based on the numerous benefits described, a literature review suggests that arts programs be inserted into health care settings, particularly because of the holistic characteristic, low cost and the potential for promoting public mental health and well-being to all involved. ${ }^{9}$ However, there are still gaps that point to the need for further research with more robust evidence of its impact on the health system. ${ }^{24}$

Accordingly, there is a movement of recognition and inclusion of arts and culture as a strategy for general health promotion in the Nordic countries. However, there is a call for further studies with strong evidence to reinforce their effectiveness and economic viability and which justifies the insertion of such public programs, such as the one that occurs successfully in the United Kingdom and pointed as an example to be followed. ${ }^{29}$

However, there is urgency in this incorporation. There are alarming data on professional exhausting, the impact on their quality of life and how much this reality compromises the quality of care provided to the population. Studies point out that much is known about working conditions, but there are few interventions proposed to change this reality considered unhealthy. ${ }^{6,28}$ We reiterate that participation in an art therapy process can contribute to minimize the stress and psychological distress of health professionals, in the extent that, in this study, it favored the quality of interaction between group members, as described in other studies. ${ }^{25,30}$

Regarding the quality of interaction established in art therapy groups, we consider that there is also the interference of the attitude and posture of the process coordinator, both in the planning of the workshops and in their own conduction. From the beginning, it is essential to be careful to propose dynamics that promote the construction of a safe, protected and confidential interaction space, which enables the building of bonds between the participants and the facilitator. ${ }^{10}$ We also observed the importance for the welcoming climate and respect to be favored and preserved during the meetings and for this, the posture of reception and acceptance of the art therapist is essential.

The promotion of greater self-knowledge was verified in a research carried out with athletes, who through the expressive activities they did, turned their eyes to themselves, recognizing and identifying their own characteristics that they did not realize before, becoming more aware of important aspects of their own personality. ${ }^{25}$

This corroborates the findings of this study, in which the professional defines the process as a therapeutic experience, which allowed them to develop potentialities, such as the ability to concentrate and self-confidence and change their way of seeing, self-knowing and facing situations in their personal and professional lives, changing postures and attitudes in their quotidian.

Thus, the participant of this research ends the experience, wishing for its continuity, observes that art therapy served as a support to face the challenges of work, recognizes its benefits and proposes its permanence in the institution. The results presented are similar to other studies that underscore the real need for health professionals to obtain resources to support them in dealing with the challenges pertinent to their work area, $, 3,27,28$ indicating the relevance of providing practices that guarantee psychological support for professionals ${ }^{6}$ and, consequently, favors their mental health.

In this regard, we consider that art therapy is an effective and viable alternative to improve the condition and promote the well-being of professionals working in health outpatient clinics, constituting a preventive form of care, especially if workshops are held at the end of weekly working hours, as well as providing personal and professional gains for participants, can be implemented in a short period of time and demands very low financial investment, using simple materials, easily available and of low cost, as demonstrated in this process. 
The fact that this study was conducted only with professionals working in a health care outpatient clinic can be considered a limitation. Thus, we believe it is necessary to carry out other research in which art therapy is applied to professionals who work in other care contexts, such as the hospital environment.

\section{FINAL CONSIDERATIONS AND IMPLICATIONS FOR PRACTICE}

The study allowed to give voice to the health professional, to understand how much he/she feels overloaded in his/her daily routine and how much the experience of participating in the group process of art therapy in the company of his/her colleagues proved to be therapeutic, rewarding and surprising, with effect on his/her health and well-being. It contributes to the reflection and discussion about health workers and the need to create therapeutic resources to support their mental health.

We think that the therapeutic effect of the process - observed and reported by the participants - derives from a set of factors, among which we highlight the opportunity to re-signify the story itself, envisioning new ways and favoring the adoption of new postures, which was provided by both interaction with colleagues, as with the art therapy process itself.

We reiterate that art therapy is a resource that should be offered to health professionals, in order to minimize the psychological suffering to which they are constantly exposed, contributing to the promotion of their mental health and, consequently, to better serve the population, solidifying the assumptions of the National Humanization Policy, according to which clients and professionals should be treated with dignity and respect.

\section{REFERENCES}

1. Organização Mundial da Saúde (OMS). Organização Pan-Americana da Saúde (OPAS). Determinantes Sociais e Riscos para a Saúde Doenças Crônicas Não Transmissíveis e Saúde Mental. Com depressão no topo da lista de causas de problemas de saúde OMS lança a campanha "Vamos conversar" [Internet]. Brasília (DF) OPAS; 2017; [cited 2019 mar 05]. Available from: http://www.paho. org/bra/index.php?option=com_content\&view=article\&id=5385:comdepressao-no-topo-da-lista-de-causas-de-problemas-de-saude-omslanca-a-campanha-vamos-conversar\&ltemid=839

2. Silva DSD, et al. Depressão e risco de suicídio entre profissionais de enfermagem: revisão integrativa. Rev Esc Enferm USP [Internet]. 2015 dec; [cited 2019 Mar 10]; 49(6):1027-1036. Available from: http://dx.doi. org/10.1590/S0080-623420150000600020

3. Rodrigues CCFM, Santos VEP. The body speaks: physical and psychological aspects of stress in nursing professionals. J Res Fundam Care Online [Internet]. 2016 jan/mar; [cited 2017 Jul 22]; 8(1):3587-96. Available from: http://dx.doi.org/10.9789/2175-5361.2016.v8i1.35873596

4. Gómez-Urquiza JL, Aneas-López AB, Fuente-Solana El, AlbendínGarcía L, Díaz-Rodríguez L, Fuente GAC. Prevalence, risk factors, and levels of burnout among oncology nurses: a systematic review. Onco Nurs Forum [Internet]. 2016 may; [cited 2016 Oct 3]; 43(3):E104-20. Available from: http://dx.doi.org/10.1188/16.ONF.E104-E120
5. Avelino DC, Silva PMC, Costa LFP, Azevedo EB, Saraiva AM, Ferreira Filha MO. Trabalho de enfermagem no centro de atenção psicossocial: estresse e estratégias de coping. Rev Enferm UFSM. [Internet] 2014; [cited 2017 Jul 20]; 4(4):718-26. Available from: http://dx.doi. org/10.5902/2179769214163

6. Silva CCS, Lira ALBC, Feijão AR, Costa IKF, Medeiros SM. Burnout e tecnologias em saúde no contexto da enfermagem na Atenção Primária à Saúde. Esc Anna Nery [Internet]. 2017; [cited 2019 Mar 2]; 21(2):e20170031. Available from: http://dx.doi.org/10.5935/14148145.20170031

7. Wilson $\mathrm{C}$, Bungay $\mathrm{H}$, Munn-Giddings $\mathrm{C}$, Boyce M. Healthcare professionals' perceptions of the value and impact of the arts in healthcare settings: A critical review of the literature. Int J Nurs Stud [Internet]. 2016 apr; [cited 2019 Mar 10]; 56:90-101. Available from: http://dx.doi.org/10.1016/j.jinurstu.2015.11.003

8. Stickley T, Wright N, Slade M. The art of recovery: outcomes from participatory arts activities for people using mental health services. $J$ Ment Health [Internet]. 2018 feb; [cited 2019 Mar 10]; 27(4):367-373. Available from: http://dx.doi.org/10.1080/09638237.2018.1437609

9. Jensen A, Bonde LO. The use of arts interventions for mental health and wellbeing in health settings. Perspect Public Health [Internet]. 2018 apr; [cited 2019 Mar 10]; 138(4):209-214. Available from: http://dx.doi org/10.1177/1757913918772602

10. Bernardo PP. A prática da arteterapia: correlações entre temas e recursos. Temas centrais em arteterapia. $4^{a}$ ed. v. 1. São Paulo: Arterapinna Editorial; 2013.

11. World Health Organization (WHO). Saúde mental: um estado de bemestar. Geneva:WHO; 2014; [cited 2019 mar 02]. Available from: https:// www.who.int/features/factfiles/mental_health/en/

12. Ministério da Saúde (BR). Secretaria de Atenção Primária à Saúde (SAPS). Departamento de Atenção Básica. Política Nacional de Práticas Integrativas e Complementares no SUS - PNPIC-SUS/ Ministério da Saúde [Internet]. Brasília (DF): Ministério da Saúde;2019; [cited 2019 mar 3]. Available from: http://dab.saude.gov.br/portaldab/ biblioteca.php?conteudo=legislacoes/pnpics

13. Ministério da Saúde (BR). Secretaria de Atenção à Saúde. Política Nacional de Humanização (HumanizaSUS) [Internet]. Brasília (DF) Ministério da Saúde; 2003. Available from: http://portalms.saude.gov. br/acoes-e-programas/humanizasus

14. Charon JM. Symbolic Interacionism: an introduction, an interpretation, an integration. 10th ed. Londres: Pearson; 2010.

15. Hsieh HF, Shannon SE. Three Approaches to Qualitative Content Analysis. Qual Health Res [Internet]. 2005 nov; [cited 2016 Oct 4]; 15(9):127788. Available from: http://dx.doi.org/10.1177/1049732305276687

16. Bernardo PP. A prática da arteterapia: correlações entre temas $e$ recursos. Mitologia indígena e arteterapia: a arte de trilhar a roda da vida. 3를 ed. São Paulo: Arterapinna Editorial; 2013. v. 2.

17. Bernardo PP. A prática da arteterapia: correlações entre temas e recursos. Arteterapia e Mitologia Criativa: orquestrando limiares. $2^{\mathrm{a}}$ ed. São Paulo: Arterapinna Editorial; 2012. v. 4.

18. Borges JL. Borges oral \& Sete noites. Tradução de Heloisa Jahn. São Paulo: Companhia das Letras; 2011

19. Medearis AS. Os sete novelos: um conto de Kwanzaa. São Paulo: Cosac Naify; 2005.

20. Mckee D. A Montanha e a Pedra. São Paulo: Martins Fontes; 1993.

21. Bernardo PP. Série: Jogos Arteterapêuticos. A Amarelinha como árvore da vida: a jornada do herói através dos contos de fadas. São Paulo: Arterapinna Editorial; 2014. v. 1.

22. Machado R. O violino cigano e outros contos de mulheres sábias. São Paulo: Editora Schwarcz S.A.; 2004

23. Saunders B, Sim J, Kingstone T, Baker S, Waterfield J, Bartlam B, et al. Saturation in qualitative research: exploring its conceptualization and operationalization. Qual Quant. 2018 jul; [cited 2019 Mar 7]; 52(4):1893907. Available from: https://doi.org/10.1007/s11135-017-0574-8 
24. Martin L, et al. Creative Arts Interventions for Stress Management and Prevention. A Systematic Review. Behav Sci (Basel) [Internet]. 2018; [[cited 2019 Mar 7]; 8(2):28. Available from: http://dx.doi.org/10.3390/ bs8020028

25. Matarazzo F. A arteterapia na preparação psicológica de atletas: uma abordagem junguiana [dissertação]. São Paulo: Pontifícia Universidade Católica [Internet]; 2013; [access 2017 jul 20]. Available from: https:// tede2.pucsp.br/handle/handle/15281

26. Bergamim MD, Prado C. Problematização do trabalho em equipe em enfermagem: relato de experiência. Rev Bras Enferm [Internet]. 2013 feb; [cited 2017 jul 20]; 66(1):134-137. Available from: http://www.scielo.br/scielo.php?script=sci_arttext\&pid=S0034$71672013000100021 \&$ Ing=en
27. Maissiat GS, Laubert L, Pai DD, Tavares JP. Work context, job satisfaction and suffering in primary health care. Rev Gaúcha Enferm [Internet]. 2015 jun; [cited 2019 Mar 7]; 36(2):42-9. Available from http://www.scielo.br/scielo.php?script=sci_arttext\&pid=S1983$14472015000200042 \&$ Ing $=\mathrm{en}$

28. Mininel VA, Baptista PCP, Felli VEA. Psychic workloads and strain processes in nursing workers of brazilian university hospitals. Rev LatinoAm Enfermagem [Internet]. 2011 apr; [cited 2017 Jul 22]; 19(2):340347. Available from: http://www.scielo.br/scielo.php?script=sci_ arttext\&pid=S0104-11692011000200016\&lng=en

29. Jensen A, Stickley T, Torrisen W, Stigmar K. Arts on prescription in Scandinavia: a review of current practice and future possibilities. Perspect Public Health [Internet]. 2017 sep; [cited 2019 Mar 7]; 137(5):268-274. Available from: http://dx.doi.org/10.1177/1757913916676853

30. Schwalbert LS, Gelain D. Arteterapia: do estresse à transcendência Rev Científica de Arteterapia Cores da Vida. 2013 jan/jun; [ cited 2019 jul 22] 20(20):1-45. Available from: http://acatarteterapia.blogspot. com/2013/07/revista-cientifica-de-arteterapia-cores.htm 